\title{
Resistencia bacteriana en los animales de producción y su riesgo en la salud pública del Ecuador
}

\author{
Mainato Guamán, Matias*; Redrovan Macancela, Santiago \\ Instituto Superior Tecnológico José Benigno Iglesias, Tecnología Superior en Producción Pecuaria, Biblián, Ecuador. \\ e-mail: matias.mainato@institutoscanar.ec
}

Palabras clave: Antibióticos, producción, resistencia bacteriana.

INTRODUCCIÓN: La resistencia bacteriana es considerada por la OMS, la OIE y la FAO como emergencia mundial. En producción pecuaria el uso indiscriminado de los antibacterianos para la prevención y tratamiento de enfermedades infecciosas, y en la alimentación utilizados como promotores de crecimiento se ha incrementado drásticamente, causando multiresistencia bacteriana por la mutación genética de las bacterias para resistir el efecto de los antibióticos, en los animales de ciclo corto de producción como pollos de carne, postura y cuyes se han encontrado residuos de antibióticos en la carne, leche y huevos; razón por la cual es un riesgo sanitario para la población que consume alimentos de origen animal, causando así varias enfermedades infecciosas difíciles de curar por la resistencia bacteriana en las personas, animales y el medio ambiente. [1]

OBJETIV0: Determinar la problemática de la resistencia bacteriana en los animales de producción en el Ecuador, mediante la revisión de artículos científicos.

MATERIALES Y MÉTODOS: Se efectuó una búsqueda actualizada en las bases de datos de las universidades del país, SciELO, Redalyc, y en los sitios de web de la OMS, FAO y la OIE. Se analizaron artículos científicos originales de las revistas que tienen mayor relevancia en la actualidad.

RESULTADOS: Varios estudios demuestran que para el control de la mastitis bovina en su mayoría utilizan Betalactámicos, Sulfonamidas y Aminoglucósidos, estos grupos de antibióticos se han encontrado como residuos en la leche y carne. Otros investigadores establecieron la resistencia a Estreptomicina (48\%) y Amoxicilina (35\%) a Staphylococcus intermedius (26\%), Staphylococcus aureus $(22 \%)$ en leche cruda. [2] En la carne de pollo varios investigadores encontraron bacterias multirresistentes como la Salmonella entérica, Salmonella infantis y la E.coli, también se ha comprobado la resistencia de Nitrofurantoína 94,8 \% y Tetraciclina $82,8 \%$ en carne de pollo. [3]

CONCLUSIONES: Varios estudios en el Ecuador demuestran que el uso inadecuado de los antibióticos en los animales de producción está causando resistencia y residuos en la leche, carne y huevos, por lo que es necesario incrementar programas de capacitación para los ganaderos y productores pecuarios del país.

\section{REFERENCIAS:}

[1] Fernández Riverón F, López Hernández J, Ponce Martínez LM, Machado Betarte C. Resistencia Bacteriana. Revista Cubana de Medicina Militar. 2003; 32(1).

[2] Bonifaz N, Conlago F. Prevalencia e incidencia de Mastitis bovina mediante la prueba de california mastitis test con identificación del agente etiológico, en paquiestancia, Ecuador. Revista de Ciencias de la Vida. 2016; 24:2.

[3] Salazar GA, Guerrero-López R, Lalaleo L, AvilésEsquivel D, Vinueza-Burgos C, Calero-Cáceres 
W. Presence and diversity of Salmonella isolated from layer farms in central Ecuador. Publimed. F1000Res. 2019; 8:235 